\title{
Allelopathic Potential of Mesua ferrea L. and Schima wallichi Reinw. ex Blume Leaf Extracts on Seedling Growth of Maize (Zea mays L.)
}

\author{
Paul Lalremsang*, C. Remlalpeka, Kalidas Upadhyaya and B. Gopichand \\ Department of Forestry, School of Earth Sciences and Natural Resources Management, Mizoram \\ University, Post Box-190, Tanhril, Aizawl-796009, Mizoram, India \\ *Corresponding author
}

\section{A B S T R A C T}

\begin{tabular}{|l|}
\hline Key w ord s \\
Allelopathy, \\
Leaf extracts, \\
Mesua ferrea, \\
Schima wallichi.
\end{tabular}

\begin{abstract}
Introduction of multipurpose trees plays an important role in agroforestry systems. It enriches the soil by providing soil cover thus providing habitat for soil flora and fauna. However, integration of trees with various crops needs to be evaluated for its allelopathic potential before its introduction into agroforestry system. The allelopathic potential of leaf extracts of Mesua ferrea and Schima wallichi was evaluated to examine its effect on the growth of Maize in laboratory bioassay as well as in pot culture. Fresh leaves of M. ferrea and $S$. wallichi were collected and the leaves were air dried for one week. The air dried leaves were ground and different concentrations (20\%, 40\%,60\% and 100\%) were prepared and compared with distilled water used as control $\left(\mathrm{T}_{0}\right)$. Results showed an inhibitory effect with an increase in the concentration of both the leaf extracts. Highest inhibitory effect on root (92.71) and shoot (86.36) length was observed in $\mathrm{T}_{4}$ and $\mathrm{T}_{3}$ for $S$. wallichi leaf extracts and highest inhibitory effect on root (75.95) and shoot (70.06) length was observed in $\mathrm{T}_{4}$ for $M$. ferrea leaf extracts when compared to control $\left(\mathrm{T}_{0}\right)$.
\end{abstract}

\section{Introduction}

Agroforestry is a land use system where agricultural crops are grown along with trees. This system plays an important role in improving soil quality, increase productivity, nutrient cycling, soil conservation and overall increase in productivity (Singh et al., 2001). A number of trees are found to produce allelopathic effect when grown together with agricultural crops. Leucaena leucocephala, Populus deltoides, Eucalyptus and Acacia species are found to produced allelochemicals and affect the performance of crops (Bansal et al., 1992; Ralhan et al., 1999; Bora et al., 1999). These allelochemicals are often released by decomposing litter affecting seed germination, growth and development of adjoining crops in agroforestry systems (Putnam, 1988). Decline in crop yields in agroforestry systems has been a result of allelopathic effects. It is important to determine the allelopathic compatibility of crops with trees before incorporating them into agroforestry systems as phytotoxins released by trees could affect the establishment of crops (King, 1979; Rice, 1979).

Due to paucity of information on the allelopathic effect of Mesua ferrea and Schima wallichi on agricultural crops, this 
study investigated the phytotoxic activity of aqueous leaf extracts of $M$. ferrea and $S$. wallichi on maize. Mesua ferrea L. belongs to the family Clusiaceae. The evergreen tree is native to wet tropical parts of Sri Lanka, India, South Nepal, Burma, Indo-China, Thailand, Sumatra and Malaysia.

It has a conical shape crown that can reach upto a height of $30 \mathrm{~m}$. It is also a state tree of Mizoram, India. Schima wallichi Reinw. ex Blume is an evergreen tree with a cylindrical crown that grows up to a height of 10-20 m belongs to the family Theaceae. This evergreen tree is indigenous to Indo-China. It is also found in northern India, Nepal, Bhutan, Southwestern China, Myanmar, Thailand, Laos and Vietnam.

Zea mays L. belongs to family Poaceae. It is the second most important cereal crop cultivated worldwide. It also occupies an important place in Indian agriculture. It is the third most cultivated cereal in India after wheat and rice. Maize is also an important agricultural crop in the Northeast India, Mizoram in particular.

\section{Materials and Methods}

\section{Bioassays}

Leaves of Mesua ferrea Linn. and Schima wallichi Reinw. ex Blume were collected from Mizoram University Campus $\left(23^{\circ} 42^{`}\right.$ to $23^{\circ} 46^{`} \mathrm{~N}$ Latitude and $92^{\circ} 38^{`}$ to $92^{\circ} 42^{`} \mathrm{E}$ Longitude, 950 above $\mathrm{msl}$ ). The collected leaves were air dried for one week at room temperature. The air dried leaves were ground and aqueous extracts were prepared by adding $100 \mathrm{~g}$ of ground leaf in 11 of distilled water and soak it for $24 \mathrm{~h}$. The extracts were filtered and diluted with distilled water taken as control. Different concentrations (20\%, 40\%, $60 \%$ and $100 \%$ ) were made from the stock solution. The experiments include five treatments including distilled water as control with three replications each.

The test crop selected was Zea mays L. which is a common cash crop of the state. Ten seeds of test crop were surface sterilized with $0.5 \%$ $\mathrm{NaClO}$ and the treated seeds were kept in each Petri-dishes lined with filter paper wetted with different concentration of extracts. The Petri-dishes were kept in growth chamber for 10 days at $20 \pm 2^{\circ} \mathrm{C}$.

The root length, shoot length, fresh weight and dry weight of root and shoot were measured and recorded. Percentage of inhibition/stimulation effect on germination over control $\left(\mathrm{T}_{0}\right)$ was calculated using the formula given by Surendra and Pota (1978), I $=100-\left(E_{2} \times 100 / E_{1}\right)$, where $I$ is the $\%$ inhibition/stimulation, $E_{1}$ the response of control and $E_{2}$ the response of treatment. The percentage of germination was calculated using the formula:

Percentage of germination $=$ No. of seeds germinated / Total number of seeds X 100

Relative elongation ratio (RER) of shoots and roots of crops was also calculated with the formula suggested by Rho and Kil (1986): R= (T/Tr) X 100; where, $\mathrm{R}$ is the relative elongation ratio, $\mathrm{T}$ is the ratio of treatment crop and $\mathrm{Tr}$ the test ratio of control.

\section{Pot culture}

For polypot culture, $2 \mathrm{~kg}$ of soil was mixed with $5 \mathrm{~g}\left(\mathrm{~T}_{1}\right), 10 \mathrm{~g}\left(\mathrm{~T}_{2}\right)$ and $15 \mathrm{~g}\left(\mathrm{~T}_{3}\right)$ of ground leaves sample to make it into four treatments including control and three seeds of test crop were sown in each polypot. The experimental design was Completely Randomized Design (CRD) with three replications. The growth parameters were recorded at 28 days after sowing. 


\section{Statistical analysis}

To determine statistical difference between the treatments, variance analysis and least significant difference (LSD) tests were performed using MS Excel software.

\section{Results and Discussion}

\section{Bioassay}

The results of the study shows that the root and shoot length of maize is concentration dependent, inhibitory effect increases with an increase in the concentration of both the extracts. The root and shoot length decreases with an increase in the level of extracts concentration. It was also observed from the study that application of higher concentration extracts on test crop is more prone to fungal attack that inhibits the growth of the tested crop. The percentage of germination was reduced with increase in the concentration of extracts (Table 1). This finding corroborate the report by Bora et al., (1999) that, the inhibitory effect of A. auriculiformis leaf extract on seed germination and seedling growth is concentration dependent. Highest inhibitory effect on root (75.94) and shoot (70.06) was found in $\mathrm{T}_{4}$ for Mesua leaf extract, while highest inhibitory effect on root (92.71) and shoot (86.36) was found in $\mathrm{T}_{4}$ and $\mathrm{T}_{3}$ for Schima leaf extract (Table 2). Maximum root and shoot elongation was observed in $T_{1}$ for both the extracts when compared to control $\left(\mathrm{T}_{0}\right)$. Similar findings were observed by Kumar et al., 2009 where leaf leachates of Melia azaderach, Morus alba and Moringa oleifera inhibited the radical and plumule growth of soybean. Oudhia and Tripathi (1999) have also observed that Parthenium extracts inhibited the root and shoot length of wheat when compared to control. A decreased in the fresh and dry weight was also observed with an increase in the concentration of the leaf extracts, wherein the highest inhibitory effect was shown by $\mathrm{T}_{4}$ (Table 4 ). The findings also conform to the findings by Sahoo et al., 2007 in which the aqueous leaf extracts of Leucaena leucocephala and Tectona grandis reduces the fresh and dry weights of maize over control. Chon et al., 2000 also reported that phenolic compounds derived from alfalfa exhibit a decrease in fresh weight with increase in the concentration of extracts. Das et al., (2012) also observed a reduction in the dry weight of root and shoot at various level of leachate.

Table.1 Germination percentage of Maize treated with Mesua ferrea and Schima wallichi leaf extracts (10 DAS)

\begin{tabular}{|c|c|c|}
\hline Treatments & GP of Maize (\%) with Mesua ferrea & GP of Maize (\%) with Schima wallichi \\
\hline $\mathrm{T}_{0}$ & $96.67 \pm 0.33$ & $96.67 \pm 0.33$ \\
\hline $\mathrm{T}_{1}$ & $90 \pm 0.00$ & $96.66 \pm 0.33$ \\
\hline $\mathrm{T}_{2}$ & $96.66 \pm 0.33$ & $90 \pm 0.6$ \\
\hline $\mathrm{T}_{3}$ & $100 \pm 0.00$ & $86.66 \pm 0.7$ \\
\hline $\mathrm{T}_{4}$ & $86.66 \pm 0.9$ & $80 \pm 1$ \\
\hline LSD@5\% & $\mathbf{1 . 7}$ & $\mathbf{2 . 4}$ \\
\hline
\end{tabular}

Values are means \pm SE of different observations 
Table.2 Effect of aqueous leaf extracts of Mesua ferrea and Schima wallichi on root length and shoot length of Maize

\begin{tabular}{|l|c|c|c|c|}
\hline & Treatments & Root length $(\mathrm{cm})$ & Shoot length $(\mathrm{cm})$ & Root:Shoot \\
\hline \multirow{4}{*}{ Mesua ferrea } & $\mathrm{T}_{0}$ & $13.72 \pm 0.72$ & $10.56 \pm 0.23$ & $1.29 \pm 0.04$ \\
\cline { 2 - 5 } & $\mathrm{T}_{1}$ & $9.17 \pm 0.51(-33.16)$ & $8.46 \pm 0.74(-19.88)$ & $1.09 \pm 0.04$ \\
\cline { 2 - 5 } & $\mathrm{T}_{2}$ & $7.50 \pm 0.50(-45.33)$ & $7.28 \pm 1.54(-31.06)$ & $1.10 \pm 0.16$ \\
\cline { 2 - 5 } & $\mathrm{T}_{3}$ & $6 \pm 0.96(-56.26)$ & $4.71 \pm 0.16(-55.39)$ & $1.28 \pm 0.23$ \\
\cline { 2 - 5 } & $\mathrm{T}_{4}$ & $3.30 \pm 0.63(-75.94)$ & $2.95 \pm 0.44(-70.06)$ & $1.11 \pm 0.06$ \\
\hline \multirow{3}{*}{ LSD } & $@ \mathbf{5 \%}$ & $\mathbf{2 . 5 5}$ & $\mathbf{2 . 9 7}$ & $\mathbf{0 . 4 9}$ \\
\cline { 2 - 5 } & $\mathrm{T}_{1}$ & $3.28 \pm 0.08(-76.09)$ & $3.27 \pm 0.36(-69.03)$ & $1.03 \pm 0.15$ \\
\cline { 2 - 5 } & $\mathrm{T}_{2}$ & $2.17 \pm 0.10(-84.18)$ & $1.90 \pm 0.15(-82)$ & $1.15 \pm 0.05$ \\
\cline { 2 - 5 } & $\mathrm{T}_{3}$ & $1.24 \pm 0.26(-90.96)$ & $1.44 \pm 0.25(-86.36)$ & $0.92 \pm 0.25$ \\
\hline \multirow{3}{*}{ LSD } & $\mathrm{T}_{4}$ & $1 \pm 0.06(-92.71)$ & $1.47 \pm 0.23(-86.07)$ & $0.70 \pm 0.10$ \\
\hline
\end{tabular}

Values in the parenthesis indicates the inhibitory (-) or stimulatory (+) effects in comparison to control $\left(\mathrm{T}_{0}\right)$

Table.3 Effect of aqueous leaf extracts of Mesua ferrea and Schima wallichi on root length and shoot length of Maize (Pot culture)

\begin{tabular}{|l|c|c|c|c|}
\hline & Treatments & Root length $(\mathrm{cm})$ & Shoot length $(\mathrm{cm})$ & Root:Shoot \\
\hline \multirow{4}{*}{ Mesua ferrea } & $\mathrm{T}_{0}$ & $6.92 \pm 1.21$ & $5.6 \pm 0.26$ & $1.25 \pm 0.25$ \\
\cline { 2 - 5 } & $\mathrm{T}_{1}$ & $10.33 \pm 3.66(+49.3)$ & $2.46 \pm 2.46(-56.1)$ & $2.05 \pm 0.41$ \\
\cline { 2 - 5 } & $\mathrm{T}_{2}$ & $16 \pm 1.52(+131.21)$ & $7.03 \pm 0.03(+25.54)$ & $2.27 \pm 0.22$ \\
\cline { 2 - 5 } & $\mathrm{T}_{3}$ & $19.13 \pm 1.13(+176.45)$ & $8.07 \pm 0.07(+44.11)$ & $2.36 \pm 0.15$ \\
\hline \multirow{3}{*}{ LSD } & $@ \mathbf{5 \%}$ & $\mathbf{8 . 3 7}$ & $\mathbf{4 . 8 2}$ & $\mathbf{1 . 0 9}$ \\
\hline \multirow{3}{*}{ LSD } & $\mathrm{T}_{1}$ & $14.05 \pm 4.93(+103.03)$ & $5.71 \pm 1.35(+2)$ & $2.25 \pm 0.43$ \\
\cline { 2 - 5 } & $\mathrm{T}_{2}$ & $16.48 \pm 0.86(+138.15)$ & $6.77 \pm 0.61(+21)$ & $2.44 \pm 0.11$ \\
\cline { 2 - 5 } & $\mathrm{T}_{3}$ & $16.08 \pm 2.21(+132.4)$ & $5.63 \pm 0.34(+13)$ & $2.83 \pm 0.29$ \\
\hline
\end{tabular}

Values in the parenthesis indicates the inhibitory (-) or stimulatory $(+)$ effects in comparison to control $\left(\mathrm{T}_{0}\right)$ 
Table.4 Effect of aqueous leaf extracts of Mesua ferrea and Schima wallichi on fresh weight and dry weight of Maize

\begin{tabular}{|c|c|c|c|c|c|c|}
\hline & Treatments & $\begin{array}{c}\text { Fresh weight } \\
\operatorname{root}(\mathrm{g})\end{array}$ & $\begin{array}{c}\text { Fresh weight } \\
\text { shoot }(\mathrm{g})\end{array}$ & $\begin{array}{l}\text { Dry weight } \\
\operatorname{root}(\mathrm{g})\end{array}$ & $\begin{array}{c}\text { Dry weight } \\
\text { shoot (g) }\end{array}$ & $\begin{array}{l}\text { Root:Shoot } \\
\text { (Dry wt.) }\end{array}$ \\
\hline \multirow{5}{*}{ Mesua ferrea } & $\mathrm{T}_{0}$ & $2.10 \pm 0.20$ & $3.34 \pm 0.16$ & $0.31 \pm 0.03$ & $0.41 \pm 0.00$ & $0.74 \pm 0.08$ \\
\hline & $\mathrm{T}_{1}$ & $\begin{array}{c}1.97 \pm 0.12 \\
(-6.19)\end{array}$ & $\begin{array}{c}2.63 \pm 0.14 \\
(-21.25)\end{array}$ & $\begin{array}{c}0.28 \pm 0.01 \\
(-9.67)\end{array}$ & $\begin{array}{c}0.33 \pm 0.03 \\
(-19.51)\end{array}$ & $0.88 \pm 009$ \\
\hline & $\mathrm{T}_{2}$ & $\begin{array}{c}1.96 \pm 0.22 \\
(-6.66)\end{array}$ & $\begin{array}{c}2.08 \pm 0.43 \\
(-37.72) \\
\end{array}$ & $\begin{array}{c}0.31 \pm 0.02 \\
(0)\end{array}$ & $\begin{array}{c}0.27 \pm 0.05 \\
(-34.14)\end{array}$ & $1.20 \pm 0.16$ \\
\hline & $\mathrm{T}_{3}$ & $\begin{array}{c}1.91 \pm 0.27 \\
(-9.04)\end{array}$ & $\begin{array}{c}1.43 \pm 0.07 \\
(-57.18)\end{array}$ & $\begin{array}{c}0.29 \pm 0.03 \\
(-6.45)\end{array}$ & $\begin{array}{c}0.19 \pm 0.00 \\
(-53.65)\end{array}$ & $1.54 \pm 0.20$ \\
\hline & $\mathrm{T}_{4}$ & $\begin{array}{c}1.02 \pm 0.21 \\
(-51.42)\end{array}$ & $\begin{array}{c}0.75 \pm 0.10 \\
(-77.54)\end{array}$ & $\begin{array}{c}0.22 \pm 0.03 \\
(-29.03)\end{array}$ & $\begin{array}{c}0.14 \pm 0.02 \\
(-65.85)\end{array}$ & $1.56 \pm 0.13$ \\
\hline LSD & $@ 5 \%$ & 0.78 & 0.82 & 0.09 & 0.10 & 0.51 \\
\hline \multirow{4}{*}{$\begin{array}{l}\text { Schima } \\
\text { wallichi }\end{array}$} & $\mathrm{T}_{1}$ & $\begin{array}{c}1.11 \pm 0.19 \\
(-47.14)\end{array}$ & $\begin{array}{c}1.12 \pm 0.16 \\
(-66.46)\end{array}$ & $\begin{array}{c}0.21 \pm 0.01 \\
(-32.25)\end{array}$ & $\begin{array}{c}0.19 \pm 0.02 \\
(-53.65)\end{array}$ & $1.12 \pm 0.06$ \\
\hline & $\mathrm{T}_{2}$ & $\begin{array}{c}0.58 \pm 0.07 \\
(-72.38) \\
\end{array}$ & $\begin{array}{c}0.71 \pm 0.11 \\
(-78.74) \\
\end{array}$ & $\begin{array}{c}0.14 \pm 0.01 \\
(-54.83) \\
\end{array}$ & $\begin{array}{c}0.14 \pm 0.02 \\
(-65.85) \\
\end{array}$ & $0.99 \pm 0.06$ \\
\hline & $\mathrm{T}_{3}$ & $\begin{array}{c}0.27 \pm 0.08 \\
(-87.14)\end{array}$ & $\begin{array}{c}0.57 \pm 0.11 \\
(-82.93)\end{array}$ & $\begin{array}{c}0.08 \pm 0.02 \\
(-74.19)\end{array}$ & $\begin{array}{c}0.13 \pm 0.02 \\
(-68.29)\end{array}$ & $0.61 \pm 0.11$ \\
\hline & $\mathrm{T}_{4}$ & $\begin{array}{c}0.23 \pm 0.05 \\
(-88.04)\end{array}$ & $\begin{array}{c}0.62 \pm 0.16 \\
(-81.43)\end{array}$ & $\begin{array}{c}0.07 \pm 0.01 \\
(-77.41)\end{array}$ & $\begin{array}{c}0.15 \pm 0.04 \\
(-63.41)\end{array}$ & $0.49 \pm 0.06$ \\
\hline LSD & @5\% & 0.50 & 0.52 & 0.07 & 0.08 & 0.29 \\
\hline
\end{tabular}

Values in the parenthesis indicates the inhibitory (-) or stimulatory (+) effects in comparison to control $\left(\mathrm{T}_{0}\right)$

Table.5 Effect of aqueous leaf extracts of Mesua ferrea and Schima wallichi on fresh weight and dry weight of Maize (Pot culture)

\begin{tabular}{|c|c|c|c|c|c|c|}
\hline & Treatments & $\begin{array}{c}\text { Fresh weight } \\
\operatorname{root}(\mathrm{g})\end{array}$ & $\begin{array}{c}\text { Fresh weight } \\
\text { shoot }(\mathrm{g})\end{array}$ & $\begin{array}{c}\text { Dry weight } \\
\text { root }(\mathrm{g})\end{array}$ & $\begin{array}{c}\text { Dry weight } \\
\text { shoot }(\mathrm{g})\end{array}$ & $\begin{array}{c}\text { Root:Shoot } \\
\text { (Dry wt.) }\end{array}$ \\
\hline \multirow{4}{*}{ Mesua ferrea } & $\mathrm{T}_{0}$ & $0.34 \pm 0.05$ & $2.03 \pm 0.29$ & $0.09 \pm 0.01$ & $0.19 \pm 0.02$ & $0.45 \pm 0.00$ \\
\hline & $\mathrm{T}_{1}$ & $\begin{array}{c}0.37 \pm 0.09 \\
(+9)\end{array}$ & $\begin{array}{c}1.58 \pm 0.34 \\
(-22.2)\end{array}$ & $\begin{array}{c}0.09 \pm 0.01 \\
(0)\end{array}$ & $\begin{array}{c}0.13 \pm 0.03 \\
(-32)\end{array}$ & $0.67 \pm 0.08$ \\
\hline & $\mathrm{T}_{2}$ & $\begin{array}{c}0.72 \pm 0.11 \\
(+112)\end{array}$ & $\begin{array}{c}2.68 \pm 0.33 \\
(+32.02)\end{array}$ & $\begin{array}{c}0.15 \pm 0.02 \\
(+67)\end{array}$ & $\begin{array}{c}0.23 \pm 0.02 \\
(+21.1)\end{array}$ & $0.65 \pm 0.03$ \\
\hline & $\mathrm{T}_{3}$ & $\begin{array}{c}0.62 \pm 0.08 \\
(+82.4)\end{array}$ & $\begin{array}{c}2.68 \pm 0.36 \\
(+32.02)\end{array}$ & $\begin{array}{c}0.14 \pm 0.01 \\
\quad(+56)\end{array}$ & $\begin{array}{c}0.23 \pm 0.02 \\
(+21.1)\end{array}$ & $0.64 \pm 0.13$ \\
\hline LSD & @5\% & 0.33 & 1.30 & 0.06 & 0.09 & 0.31 \\
\hline \multirow{3}{*}{$\begin{array}{l}\text { Schima } \\
\text { wallichi }\end{array}$} & $\mathrm{T}_{1}$ & $\begin{array}{c}0.61 \pm 0.17 \\
(+79.41)\end{array}$ & $\begin{array}{c}2.46 \pm 0.59 \\
(+21.2)\end{array}$ & $\begin{array}{c}0.13 \pm 0.03 \\
(+44.44)\end{array}$ & $\begin{array}{c}0.21 \pm 0.04 \\
\quad(+11)\end{array}$ & $0.63 \pm 0.03$ \\
\hline & $\mathrm{T}_{2}$ & $\begin{array}{c}0.85 \pm 0.05 \\
(+150)\end{array}$ & $\begin{array}{c}2.81 \pm 0.26 \\
(+38.42)\end{array}$ & $\begin{array}{c}0.16 \pm 0.00 \\
(+78)\end{array}$ & $\begin{array}{c}0.23 \pm 0.01 \\
(+21.1) \\
\end{array}$ & $0.70 \pm 0.04$ \\
\hline & $\mathrm{T}_{3}$ & $\begin{array}{c}0.57 \pm 0.13 \\
(+68)\end{array}$ & $\begin{array}{c}1.91 \pm 0.22 \\
(-6)\end{array}$ & $\begin{array}{c}0.11 \pm 0.01 \\
(+22.22)\end{array}$ & $\begin{array}{c}0.16 \pm 0.01 \\
(-16)\end{array}$ & $0.66 \pm 0.02$ \\
\hline LSD & @5\% & 0.45 & 1.45 & 0.07 & 0.11 & 0.11 \\
\hline
\end{tabular}

Values in the parenthesis indicates the inhibitory (-) or stimulatory (+) effects in comparison to control $\left(\mathrm{T}_{0}\right)$ 
Table. 6 Effect of aqueous leaf extracts of Mesua ferrea and Schima wallichi on number of lateral roots of Maize (Pot culture)

\begin{tabular}{|l|c|c|}
\hline & Treatments & Number of lateral roots \\
\hline \multirow{4}{*}{ Mesua ferrea } & $\mathrm{T}_{0}$ & $8.33 \pm 0.57$ \\
\cline { 2 - 3 } & $\mathrm{T}_{1}$ & $5.55 \pm 1.92(-33.4)$ \\
\cline { 2 - 3 } & $\mathrm{T}_{2}$ & $7.77 \pm 0.96(-7)$ \\
\cline { 2 - 3 } & $\mathrm{T}_{3}$ & $8.44 \pm 0.98(+1.32)$ \\
\hline \multirow{3}{*}{ Schima wallichi } & $@ \mathbf{5 \%}$ & $\mathbf{4 . 7 5}$ \\
\cline { 2 - 3 } & $\mathrm{T}_{1}$ & $7.77 \pm 1.74(-7)$ \\
\cline { 2 - 3 } & $\mathrm{T}_{2}$ & $9.99 \pm 0.33(+20)$ \\
\cline { 2 - 3 } & $\mathrm{T}_{3}$ & $8.11 \pm 1.56(-3)$ \\
\hline
\end{tabular}

Values in the parenthesis indicates the inhibitory (-) or stimulatory (+) effects in comparison to control $\left(\mathrm{T}_{0}\right)$

\section{Pot culture}

The response of leaf extracts on the test crop in pot culture shows opposite trends when compared to bioassay. The root and shoot length increases with an increase in the concentration of both the leaf extracts. Highest stimulatory effect on root (176.45) and shoot (44.11) was shown by $\mathrm{T}_{3}$ for Mesua leaf extract, while the highest stimulatory effect on root (138.15) and shoot (21) in $\mathrm{T}_{2}$ for Schima leaf extract (Table 3). An inhibitory effect on the shoot length was observed in $\mathrm{T}_{1}$ for Mesua leaf extract, which could be due to the reduction in cell division of the tested crop (Gholami et al., 2011). The fresh and dry weight of roots and shoots also increase with the concentration of the extracts (Table 5). Stimulatory effects are more pronounce in Mesua leaf extract at higher concentration when compared to Schima leaf extract treatment which shows an inhibitory effect on the fresh and dry weights at $T_{3}$. However, a stimulatory effect was more pronounce when compared to overall inhibitory effect in pot culture. The production of lateral roots shows a stimulatory effect at higher concentration when compared to control but non-significant $(p<0.05)$ Table 6 . The above findings are in par with the finding by Mali and Kanade
(2014) where extracts of Cynodon dactylon caused a stimulatory effect on the root and shoot length when compared to control. Dhole et al., (2011) also found that an aqueous extract of Portulaca oleracea cause a stimulatory effect on seed germination, rootshoot length and seedling growth on Sorghum vulgare. Bharath et al., (2014) reported that the dry weight of maize was found to be increased when the concentration of ginger aqueous extracts were increase. Jabeen and Ahmed (2009) also reported that the shoot extract of Fumaria indica enhanced the growth of maize and the fresh weight increases with an increase in the concentration of extracts. Musyimi et al., 2015 also found that $T$. diversifolia leaf extract stimulates root and shoot dry weight.

This experiment was for the first time conducted to demonstrate the allelopathic potential of Mesua ferrea and Schima wallici on agricultural crops. The test crop used in this experiment is one of the most important crops grown in the state and an important cash crop of the region. Agroforestry includes growing of crops in combination with multipurpose tree species. Several crops are grown in between rows of trees in homegardens, to conserve soil moisture and act as cover crops in the field. Since, Mesua 
ferrea and Schima wallichi constitute a major component in the homegardens, there is a need to evaluate its allelopathic potential before its introduction into agroforestry systems. The study reveals that Mesua ferrea is a better component tree in agroforestry systems than Schima wallichi and a better multipurpose tree species to be introduced into agroforestry systems.

\section{Acknowledgements}

The authors would like to thank the Head, Department of Forestry, Mizoram University for providing necessary equipments during the study.

\section{Conflict of interest}

Authors declared that there is no conflict of interest.

\section{References}

Bansal, G.L., Nayyer, H., Bedi, Y.S. 1992. Allelopathic effect of Eucalyptus macorrhyncha and E. yoymanii on seedling growth of wheat (Triticum aestivum) and radish (Raphanus sativus). Indian J. Agri. Sci., 62: 771772.

Bharath, N.H., Kumar, N.K.H., Jagannath, S. 2014. Allelopathic efficacy of Zingiber officinale Rosc. aqueous leaf, stem and rhizome extract on early seedling growth of Zea mays L. Global J. Biol. Agri. Health Sci., 3(3): 166-170.

Bora, I.P., Singh, J., Borthakur, R., Bora, E. 1999. Allelopathic effect of extracts of Acacia auriculiformis on seed germination of some agricultural crops. Annals of Forestry, 7: 143-146.

Chon, S., Choi, S.K., Jung, S., Jang, H.G., Pyo, B.S., Kim, S.M. 2000. Effect of Alfalfa leaf extracts and phenolic allelochemicals on early seedling growth and root morphology of Alfalfa and barnyard grass. Crop Protection, 21: 1077-1082.

Das, C.R., Mondal, N.K., Aditya, P., Datta, J.K., Banerjee, A., Das, K. 2012. Allelopathic potentials of leachates of leaf litter of some selected tree species on gram seeds under laboratory conditions. Asian J. Exp. Biol. Sci., 3(1): 59-65.

Dhole, J.A., Bodke, S.S., Dhole, N.A. 2011. Allelopathic effect of aqueous extract of five selected weed species on seed mycoflora, seed germination and seedling growth of Sorghum vulgare Pers. Res. J. Pharmaceutical Biol. Chem. Sci., RJPBCS., 2: 142-148

Gholami, B.A., Faravani, M., Kashki, M.T. 2011. Allelopathic effects of aqueous extracts from Artemisia kopetdanghensis and Satureja hortensison growth and seed germination of weeds. J. Appl. Environ. Biol. Sci., 1: 283-290.

Jabeen, N., Ahmed, M. 2009. Possible allelopathic effects of three different weeds on germination and growth of maize cultivars. Pak. J. Bot., 41(4): 1677-1683.

King, K.F.S. 1979. Agroforestry and the utilization of fragile ecosystems. Forest Ecol. Management, 2: 161-168

Kumar, M., Malik, V., Joshi, M. 2009. Allelopathic effects of Melia azaderach, Morus alba and Moringa oleifera on germination, radical and plumule growth of Glycine max. Range Management Agroforestry, 30: 167168.

Mali, A.A., Kanade, M.B. 2014. Allelopathic effect of two common weeds on seed germination, root-shoot length, biomass and protein content of jowar. Annals of Biol. Res., 5(3): 89-92.

Musyimi, D.M., Okelo, L.O., Okello, V.S., Sikuku, P. 2015. Allelopathic potential 
of Mexican sunflower [ Tithonia diversifolia (hemsl) a. Gray] on germination and growth of cowpea seedlings (Vigna sinensis L.). Scientific Agriculturae, 12(3): 149-155.

Oudhia, P., Tripathi, R.S. 1999. Allelopathic effects of Parthenium hysterophours, Lantana camara and Ageratum conyzoides on germination and seedling vigour of wheat and selected rabi weeds, (In abstracts, II World Congress on Allelopathy), Critical Analysis and future prospects (Ed. A.U. Malik) 142, Thunder-bay, Ontario, Canada, Lakehead University.

Putnam, A.R. 1988. Allelochemicals from plants as herbicides. Weed Technol., 2: 510-518.

Ralhan, P.K., Singh, A., Dhanda, R.S. 1992. Performance of wheat as intercrop under poplar (Populus deltoides Bartr.) plantations in Punjab (India).
Agroforestry Systems, 19: 217-222.

Rho, B.J., Kil, B.S. 1986. Influence of phytotoxin from Pinus rigida on the selected plants. J. Natural Sci., 5: 1927.

Rice, E.L. 1979. Allelopathy- an update. Botanical Rev., 45: 15-109.

Sahoo, U.K., Jeeceelee, L., Meitei, C.B. 2007. Allelopathic effects of Leucaena leucocephala and Tectona grandis on germination and growth of maize. Allelopathy J., 20: 135-144.

Singh, H.P., Batish, D.R., Kohli, R.K. 2001. Allelopathy in agroecosystems: an overview. In: Kohli, R.K., Singh, H.P., Batish, D.R. (Eds.), Allelopathy in Agroecosystems. Haworth Press, USA

Surendra, M.P., Pota, K.B. 1978. The allelopathic potentials from root exudates from different ages of Celosia argenta L. Natural Academy of Sci. Lett., 1: 56-58.

\section{How to cite this article:}

Paul Lalremsang, C. Remlalpeka, Kalidas Upadhyaya and Gopichand, B. 2017. Allelopathic Potential of Mesua ferrea L. and Schima wallichi Reinw. ex Blume Leaf Extracts on Seedling Growth of Maize (Zea mays L.). Int.J.Curr.Microbiol.App.Sci. 6(3): 2248-2255. doi: http://doi.org/10.20546/ijcmas.2017.603.257 